\title{
The Effect of Mahkota Dewa (Phaleria macrocarpa) Leaf Extract on the Mucin 1 Expression in Mice Colonic Epithelial Cells Induced by Dextran Sodium Sulfate (DSS)
}

\author{
Kusmardi Kusmardi ${ }^{1-3, *}$, Natasha Yemima Situmorang ${ }^{4}$, Endah Zuraidah ${ }^{5}$, Ari Estuningtyas ${ }^{6}$, Aryo Tedjo ${ }^{2,7}$
}

\author{
Kusmardi Kusmardi ${ }^{1-3, *}$, Natasha \\ Yemima Situmorang ${ }^{4}$, Endah \\ Zuraidah $^{5}$, Ari Estuningtyas ${ }^{6}$, \\ Aryo Tedjo ${ }^{2,7}$
}

'Department of Anatomic Pathology, Faculty of Medicine - Universitas Indonesia, Jakarta, INDONESIA.

${ }^{2}$ Drug Development Research Center, Indonesia Medical Education and Resesarch Institute (IMERI), Universitas Indonesia, Jakarta, INDONESIA.

${ }^{3}$ Human Cancer Research Center, IMERI,

Universitas Indonesia, Jakarta, INDONESIA.

${ }^{4}$ Faculty of Medicine, Universitas Indonesia, Jakarta, INDONESIA.

${ }^{5}$ Department of Anatomic Pathology, Faculty of Medicine - Universitas Indonesia, Jakarta INDONESIA.

${ }^{6}$ Department of Pharmacology and

Therapeutic, Faculty of Medicine, Universitas Indonesia, Jakarta, INDONESIA.

'Department of Medical Chemistry, Faculty of Medicine, Universitas Indonesia, Jakarta INDONESIA.

\section{Correspondence}

\section{Kusmardi Kusmardi}

Department of Anatomic Pathology, Faculty of Medicine; Drug Development Research Center, Indonesia Medical Education and Resesarch Institute (IMERI), Human Cancer Research Center IMERI, Universitas Indonesia, Jakarta, INDONESIA

E-mail: kusmardi.ms@ui.ac.id

History

- Submission Date: 25-08-2021;

- Review completed: 06-09-2021;

- Accepted Date: 14-09-2021.

DOI : 10.5530/pj.2021.13.192

Article Available online

http://www.phcogj.com/v13/i6

\section{Copyright}

(C) 2021 Phcogj.Com. This is an openaccess article distributed under the term of the Creative Commons Attribution 4.0 International license.

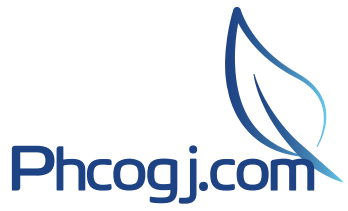

\begin{abstract}
Background: Inflammatory bowel disease is a chronic inflammation caused by the malignant inflammation response and if not treated, could lead to colorectal cancer. One of the researched treatment is mahkota dewa (Phaleria macrocarpa) leaf extract that has flavonoid compound known to reduce inflammation. This study was aimed to prove that mahkota dewa leaf extract could reduce inflammation of mice colon induced with dextran sodium sulfate (DSS) and observe MUC1 expression from colon epithelial crypt of Lieberkuhn. Methods: This was a laboratory experiment using biological material (paraffin block) taken from 28 mice and divided into 5 groups: normal, aspirin, low and high dose mahkota dewa, and negative control. They were processed into immunohistochemistry and stained microscopic slides. Afterwards, they were observed with 400x magnification and 5 field-of-view of mice colon crypt of lieberkuhn. Then MUC1 expression was counted using ImageJ to obtain mean immunohistochemistry score and analyzed with SPSS. Results: There were significant reduction of MUC1 expressions from normal, aspirin, and high dose mahkota dewa groups compared to the negative control group. The result shown MUC1 expression from high dose mahkota dewa $(M=149.90, S D=3.81)$ and aspirin $(M=158.92, S D=5.28)$ were closer to normal group $(M=148.02, S D=5.28)$. There were no significant results between negative $(M=175.39, S D=14.30)$ and low dose mahkota dewa group $(M=149.90, S D=5.02)$. Conclusion: There was a reduction of MUC1 expression in DSS-induced mice colonic epithelial cells for high dose mahkota dewa group. This shown that high dosage mahkota dewa leaf extract could reduce inflammation like aspirin. Key words: Mahkota dewa (Phaleria macrocarpa), Anti-inflammatory agent, Colon epithelial cell, MUC 1 expression, Inflammatory bowel disease.
\end{abstract}

\section{INTRODUCTION}

Inflammatory bowel disease (IBD), with ulcerative colitis (UC) and Crohn's disease (CD) are chronic disease that can burden most population, either for the patient's quality of life, health worker, or society. It was estimated in the United States, there are two million people that have IBD and will increase to four million in $2030 .^{1,2}$ In contrast, to Asian countries which previously have low incidence rates of IBD, recently have increased in the last decade following the advancement of the country themselves. ${ }^{2}$ In Indonesia, according to a research in 2011-2012, there were an average of 0.55 per 100,000 cases of people suffering UC, 0.33 per 100,000 cases of $C D$, and 0,88 per 100,000 people with IBD. ${ }^{3}$ Even though the cases was not as high as those in urban areas such as Guangzhou in China, the disease will increase if there is no further management. ${ }^{4} \mathrm{IBD}$ is also known as one of the risk factors for colorectal cancer (CRC), especially if the inflammation involves large areas of the colon in a long period. ${ }^{5,6}$ This cancer has been one of the biggest medical problems in Indonesia, with 30,017 new cases in 2018 and ranked as the $4^{\text {th }}$ commonest cancer for all genders in the same year. ${ }^{7}$

There are 3 main pathways for colorectal cancer (CRC), which are microsatellite instability (MSI), chromosomal instability (CIN), inflammatory pathway. ${ }^{8}$ According to a study in 2013, it was found that the expression of COX2 in cancer cell was $58 \%$ and activation of $\mathrm{Nf}-\mathrm{kB}$ in cancer cell was around $70 \%{ }^{9}$ These genes are important components in the inflammation signaling pathway that caused IBD and can lead to tumors. ${ }^{8}$ Beside that, other gene that contributed to this was mucin 1 or MUC1, which known have an important role as a modulator of inflammation caused by pathogens. ${ }^{10,11}$ In IBD condition, the expression of MUC1 is altered and upregulated after the stimulation of TNF-a, a proinflammatory cytokine. ${ }^{10,12}$ Higher expression of MUC1 will cause more severe inflammation conditions. MUC1 can be recognized by the immune system and usually used during activation of the adaptive immune system to remove the lesion. However, if nothing will be done, it can cause cancer because of the blockage in the apoptosis process in the epithelial cell. ${ }^{11}$

In curing the inflammation in the colon and prevent Colorectal Cancer, there are three classes of biological agents used to treat IBD. These are the anti-integrin, the antagonist to tumor necrosis factor (TNF), and inhibitor of interleukin (IL) 12 or 23. However, it was observed that $20-30 \%$ patients experienced primary nonresponse while another $30 \%$ have become refractory due to secondary loss of response. ${ }^{13}$ Another medication that used to treat inflammation in the colon is aspirin, which a nonsteroid anti-inflammatory drug (NSAIDs), it also has an anti-cancer effect due to its ability to stop cell division. ${ }^{14,15}$ However, due it is not a complete cure and potency to stop cell division or cause apoptosis,

Cite this article: Kusmardi K, Situmorang NY, Zuraidah E, Estuningtyas A, Tedjo A. The Effect of Mahkota Dewa (Phaleria macrocarpa) Leaf Extract on the Mucin 1 Expression in Mice Colonic Epithelial Cells Induced by Dextran Sodium Sulfate (DSS). Pharmacogn J. 2021;13(6): 1509-1515. 
there will be an increase the tendency for bleeding and complication, such as epistaxis, purpura, or occult gastrointestinal bleeding. ${ }^{14-16}$

From the available medications above, it shows that the wisest approach for IBD or inflammation in the colon is prevention or finding alternative medicines, such as herbal medicine. Even though the etiology is not fully understood, there were several studies researching factors that can prevent the inflammatory or finding complementary and alternative medicine, which includes herbal medicine, to treat the patient. ${ }^{15,17} \mathrm{~A}$ study found an additional class of compounds that could give potential health benefit for IBD prevention, which is called polyphenols. ${ }^{15}$ Majority of polyphenols, such as flavonoids, is not absorbed directly, thus it can reach the colon..$^{15}$ An example of a plant with polyphenols compound in it is mahkota dewa ( $P$. macrocarpa), especially its leaves and fruits. ${ }^{18}$ In addition, leaf extract of $P$. macrocarpa has an antiinflammatory effect like aspirin because both can inhibit the activation of NF- $\kappa$ B, lessen COX2, $\beta$-catenin, and other inflammatory gene. ${ }^{19-21}$ Thus to strengthen the previous findings, this study observes MUC1 expression that should be reduced because the flavonoid in mahkota dewa leaf extract should inhibit the trigger for this protein, which is the $\mathrm{NF}-\kappa \mathrm{B}$ and other inflammatory gene.

This study was conducted to examine the effect of Mahkota dewa ( $P$. macrocarpa) leaf extract that was expected to decrease the expression of MUC1 in the colon and give a stronger evidence to use it as an anti-inflammatory drug. For that, this study used mice that have been given dextran sodium sulfate (DSS), which will induce inflammation in the colon and shown the condition of epithelial cell alike in IBD cases by disrupt the integrity, function of mucosal barrier in the colon or intestine, and immune response change, such as T helper 1 and 2. 22-24 At the end, there will be an observation of mice colon to see and compare between mice that was given different treatment in treating the inflammation in the colon.

\section{METHODS}

\section{Study Design}

This research was experimental research using Swiss Webster mice with in vivo experiments. The mice colon tissues that were used in this research has been processed into a biological material or paraffin block from prior research correlated to the topic. The effect would be histopathologically observed and planned as a comparison, parallel, and randomly using the same process that have been used previously by Kusmardi et al. and Suprapti et al. ${ }^{25,26}$ This research was done after ethical approval from The Health Research Ethics Committee, Faculty of Medicine, Universitas Indonesia, with ethical number of : 0891/ UN2.F1/ETIK/2018

\section{Materials}

All the chemicals and solvents in the experiment were analytical grade. The extract was obtained from the laboratory of IPB Biopharmaceutical Study Center, Bogor, which was a mahkota dewa (P.macrocarpa) leaf extract in a form of dry powder. Dextran sodium sulfate (DSS) was obtained from MP Biomedicals LLC and Aspirin were taken from a local drugstore in Jakarta.

\section{Experimental animals}

The animals that used were male Swiss Webster mice with the age of 12 weeks and have a weight around 25 grams, which were obtained from The Animal Laboratory of the Center for Health Research and Development, Ministry of Health, Jakarta. There were 28 mice used and divided into 5 groups, which consisted of normal mice $(\mathrm{N})$ group, negative control (NC) group, aspirin (A) group, and 2 groups of mice that would be given mahkota dewa leaf extract, but with different doses. Thus, there were 6 mice in 3 groups and 5 mice in the other 2 group.
There were 2 groups that were given mahkota dewa leaf extract as the treatment group, one was given $25 \mathrm{mg} / \mathrm{kg}$ body weight/day, and the other $12.5 \mathrm{mg} / \mathrm{kg}$ body weight/day and before received each treatment there was an acclimatized under laboratory condition for 1 week. The animals were kept under standard condition of temperature and relative humidity.

\section{Sample Size Determination}

This research used male Swiss Webster mice, with the quantity determined using Federer formula. The formula is $(\mathrm{t}-1)(\mathrm{n}-1) \geq 15$, with $\mathrm{t}$ for depicting the treatment groups and $\mathrm{n}$ for how many mice needed for each group. There were 5 different treatments given to these mice. For the calculation were:

$$
\begin{aligned}
& (\mathrm{t}-1)(\mathrm{n}-1) \geq 15 \\
& (\mathrm{n}-1) \geq 15:(5-1) \\
& (\mathrm{n}-1) \geq 3.75 \\
& \mathrm{n} \geq 4.75
\end{aligned}
$$

From the calculation, each treatment group has to be compromised with at least 5 mice. In this experiment each group has 6 mice in the 3 group and 5 mice in the other 2 group, hence there are 28 mice used for this research.

\section{Sample preparation}

After 7 weeks of experiment, the mice were euthanized using cervical dislocation. The colon of the mice were excised, cleaned, and then rinsed with water. Parts of the colon tissue were fixed in $10 \%$ formalin buffer for 1 to 2 days and then dehydrated. After this process, the pieces of colon tissue were inserted into a stratified xylene solution. Then, the tissue was soaked and embedded in paraffin medium on the box cassette which has been marked. This paraffin blocks were cut with the microtome machine at the thickness of 3-5 $\mu \mathrm{m}$. Lastly the pieces were inserted into a water bath with $40-50{ }^{\circ} \mathrm{C}$, attached to a glass slide and let it dry at $40^{\circ} \mathrm{C}$ for 1 hour.

\section{Immunohistochemical staining}

The paraffin blocks of colon tissue were attached to a special glass object. Tissue samples were dried at $37{ }^{\circ} \mathrm{C}$ and continued to a warmer temperature of $60 \mathrm{C}$. After heating process, the samples were deparaffinized and rehydrated. The tissue was then washed with running water for 5 minutes and continued with endogenous peroxidase blocking by inserting the tissue into a $0.5 \% \mathrm{H}_{2} \mathrm{O}_{2}$ solution mixed with ethanol for 30 minutes. Then, the tissue was washed again for running water for 5 minutes and perform antigen retrieval. In this process, the washed tissue was briefly inserted into a container containing a Tris-EDTA solution and heated in a chamber decloaking device for 10 minutes at $96 \mathrm{C}$.

The tissue was cooled for 45 minutes and the step was followed by washing it with phosphate-buffered saline $\mathrm{pH} 7.4$ for 5 minutes. The sections were then blocked with blocking background sniper for 15 minutes and incubated for 60 minutes with primary antibodies in a humidified chamber. After the incubation step, the sections experienced immunoreactivity and caused chromogenic reaction which shown as the color of brown and blue. The number of brown - yellow (perceived as positive) and blue (perceived as negative) were then counted with the help of Image J application as "cell counter" plugin.

From the histology of colon tissue samples from every treatment were performed using Leica light microscope and Sigma camera with 400x magnification. Then the examination of each sample were conducted 5 fields of view. Using Indomikrom software, the image was taken in the format of TIF. From those photos, the expression of 
protein will be analyzed using ImageJ or IHC prolifier. IHC profiler gives scoring influenced by visual bias, which can be analyzed and processed by an advance digital image processing system using color deconvolution and computerized pixel profiling. ${ }^{27}$ Thus, there will be an automated scoring according to the respective image. The final score will be shown in semiquantitative way, such as high positive, positive, low positive, or negative. ${ }^{27}$ If there are brown color from the cytoplasmic and membranous staining, they are considered as positive for immunoreaction to MUC1. ${ }^{28}$. The immunohistochemistry score (H-Score) were calculated using the formula:

$\{(\%$ high positive $\mathrm{x} 4)+(\%$ positive $\mathrm{x} 3)+(\%$ low positive $\mathrm{x} 2)+(\%$ negative $\mathrm{x} 1$ )

100

\section{Data Analysis}

From the result of IHC analysis, the data were analyzed using a oneway Anova test. In which it was processed using Post Hoc test to see the differences from each treatment. All the data were analyzed using IBM SPSS Statistic Version 24 program. The data from the experiment is presented in the form of mean $\pm \mathrm{SD}$ and all of the statistical analysis would be proven if $\mathrm{p}<0,05$.

\section{RESULTS}

The results shown the data of positive expression of MUC1 in the epithelial cell of mice colon, specifically the crypt of lieberkuhn taken the slides (Figure 1). The microscopic slides were taken from five groups of mice that has been given different treatment. There were 3 groups that each has 6 microscopic slides, with one slide representing one mice. These groups were the normal group, aspirin group, and low dose of mahkota dewa group. While the other 2 groups, negative control and high dose of mahkota dewa group, each has 5 microscopic slides of mice colon from different specimens. The microscopic slide was given Immunohistochemistry (IHC) staining and analysed using ImageJ to examined the expression of protein in the epithelial cell on the colon crypt of lieberkuhn. From the expression, the optical density score or $\mathrm{H}$-score was calculated and inserted as the data

A one-way Anova was conducted to compare statistical different treatment towards an inflamed colon on mean $\mathrm{H}$-score in not an inflamed colon or normal group, aspirin group, low dose and high dose of mahkota dewa group. There is a statistically significant difference between the treatment groups $(\mathrm{F}(4,23)=12.15, \mathrm{p}<.001)$. Post hoc testing using the Tukey HSD revealed a significant difference between mean $\mathrm{H}$-score for a negative group $(\mathrm{M}=175.39, \mathrm{SD}=14.30)$ with three other groups, which were normal group $(\mathrm{M}=148.02, \mathrm{SD}=5.28)$, high dose of mahkota dewa group ( $\mathrm{M}=149.90, \mathrm{SD}=3.81)$, and aspirin group $(M=158.92, S D=5.28)$. The test also shows significant difference in low doses of mahkota dewa $(\mathrm{M}=149.90, \mathrm{SD}=5.02)$ with high doses of mahkota dewa group and normal group.

In figures 2 and 3 , the data shown the highest mean difference between the significant group was between negative and normal group $\left(\mathrm{M}_{\mathrm{dif}}=27.37, \mathrm{SD}=4.47, \mathrm{p}<.001\right)$, followed by negative and high dose of mahkota dewa group $\left(\mathrm{M}_{\mathrm{dif}}=25.49, \mathrm{SD}=4.67, \mathrm{p}<.001\right)$. Another significant group for negative group, which was the group that only given DSS to induce inflammation in the colon, was Aspirin group $\left(\mathrm{M}_{\text {dif }}=16.46, \mathrm{SD}=4.47, \mathrm{p}=.010\right)$ However, it was much lower than the previous group. There were also other groups which have significant relationship with lower mean $\mathrm{H}$-score differences, which were low doses of mahkota dewa and normal group $\left(\mathrm{M}_{\mathrm{dif}}=16.24, \mathrm{SD}=4.26\right.$, $\mathrm{p}=.007)$, lastly between the low and high dose group of mahkota dewa group $\left(\mathrm{M}_{\mathrm{dif}}=14.37, \mathrm{SD}=4.47, \mathrm{p}=.028\right)$.

In comparison, there were also groups pairings that were not significant in the post hoc test, even differences was observed between their mean
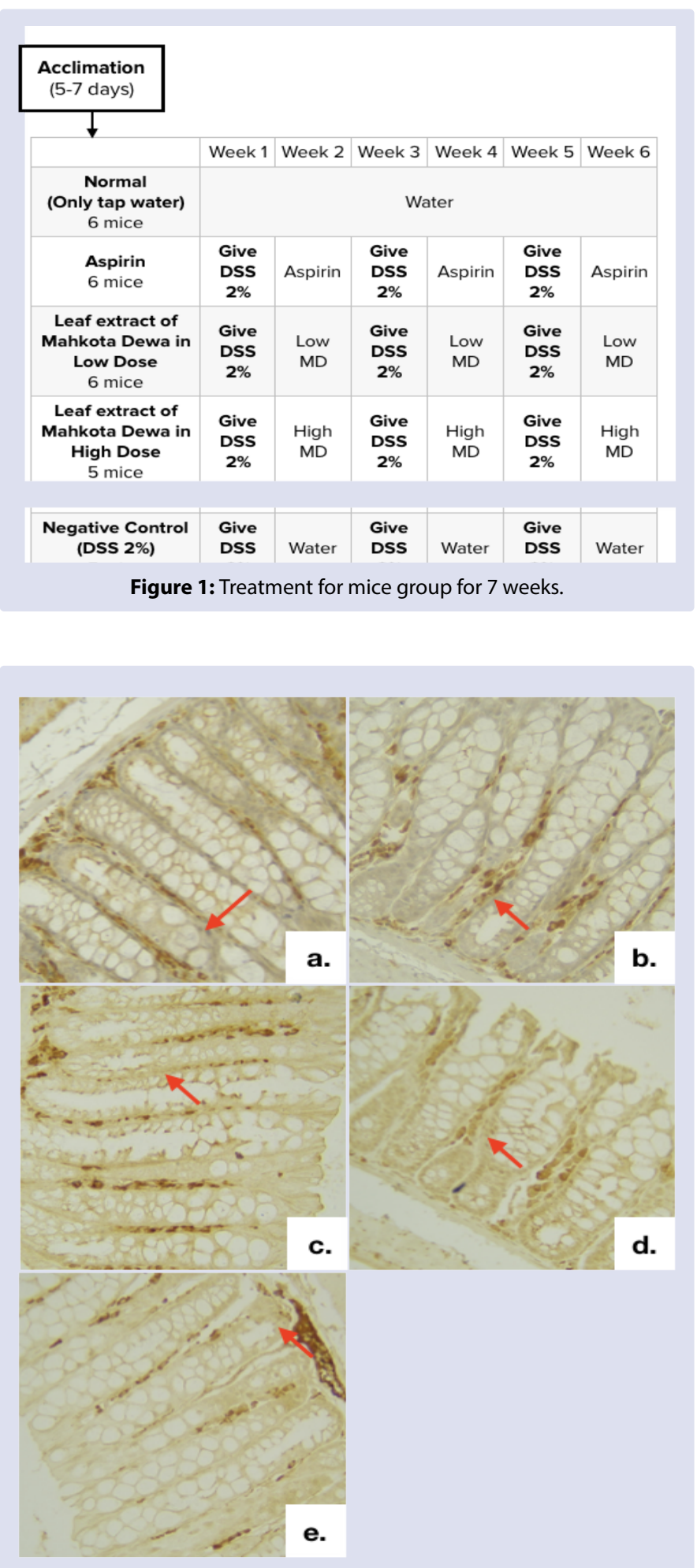

Figure 2: Microscopic appearance of each treatment group with IHC staining showing MUC1 expression. Magnification: 400x. (a) negative control group (b) normal group (c) aspirin group (d) low dose mahkota dewa group (e) high dose mahkota dewa group.

$\mathrm{H}$-score, which were the pairings between negative group and low dose of mahkota dewa group $\left(\mathrm{M}_{\mathrm{dif}}=11.12, \mathrm{p}=.128\right)$, the normal group with aspirin group $\left(\mathrm{M}_{\mathrm{dff}}=10.9, \mathrm{p}=.112\right)$ and with high dose of mahkota dewa group $\left(\mathrm{M}_{\mathrm{dif}}=1.88, \mathrm{p}=.993\right)$. The pairings between aspirin and both mahkota dewa group, the high dose $\left(\mathrm{M}_{\text {dif }}=5.34, \mathrm{p}=.721\right)$ and low dose $\left(\mathrm{M}_{\mathrm{dif}}=9.03, \mathrm{p}=.288\right)$, were also not significant. 


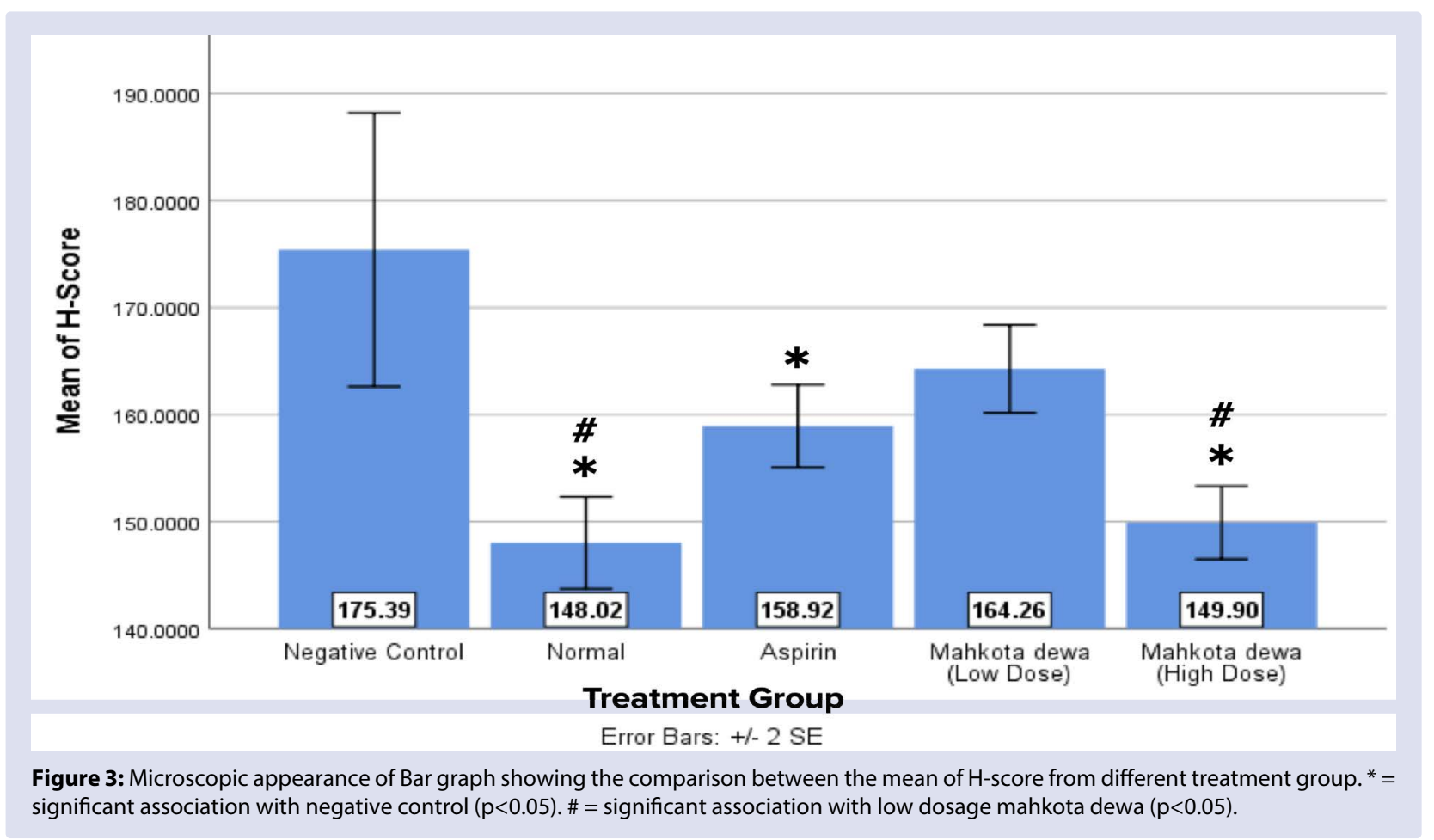

\section{DISCUSSION}

Gastroenterology diseases are one of the major health problems in Indonesia, with one it is Inflammatory Bowel Disease (IBD) and Colorectal cancer (CRC). Although it is not as prevalent as it is in the West, there was an increase of IBD cases in the last decade in Asia. ${ }^{2}$ An important thing to take note is that IBD is known as a major risk factor for Colorectal Cancer, especially if the inflammation is not treated and spreads in a large area of the colon. According to World Health Organization GLOBOCAN in 2018, CRC is the 4th most common cancer in Indonesia. ${ }^{7}$ Hence, in order to reduce the risk of CRC, researchers tried to find an optimal treatment for IBD, as the known treatment has some side effect of increasing the chances of gastrointestinal bleeding. One alternative is herbal medicine, specifically Phaleria Macrocarpa (mahkota dewa) leaf extract, which has already been researched by observing protein expression that correlates with the inflammatory pathway, such as iNOS, b-catenin, and COX-2. ${ }^{26}$ However, there should be further studies to give a stronger evidence in the effectiveness of the plant to reduce inflammation. This study aims to observe the effectiveness of mahkota dewa leaf extract in reducing Mucin 1 (MUC1), another protein that is involved with the inflammatory process, in reducing the colon inflammation of mice.

\section{Correlation between the $\mathrm{H}$-Score and the Treatment for the Groups}

These past few years, there are various studies which focus on the effectiveness of herbal medicine as an alternative for disease treatments, including colon inflammation. By simulating the inflammation of the colon in mice, previous studies used dextran sodium sulfate (DSS) as an inflammatory inducer and have been used to see pathogenesis of inflammatory bowel disease. ${ }^{22,29}$ Thus, the group of mice would be firstly given DSS for few weeks, except for the control group, and then given the treatment to be observed. This method also have been applied to various research to observe effect of herbal medicine.

A similar study that investigates the effect of mahkota dewa as one of possible treatments for colon inflammation has been done by Suprapti et al. in 2014. They have found that the expression of protein such as
iNOS and b-catenin, and COX-2, which supposed to be increased in the colon epithelial cells after being induced with DSS for inflammation, have a close immunohistochemistry score or $\mathrm{H}$-score with the aspirin and a control group. ${ }^{26}$ This was shown that there were reduced expression of inflammatory agents and thus reduces the inflammation of the colon. These results were also supported by later researches, such as a study by Estuningtyas et al. and Kusmardi et al. (2018) that found an ethanol extract of mahkota dewa leaf inhibited the inflammation of mice colon..$^{23,25}$

In this study, the methods used is the same as the previous research mentioned above, with the difference in the observed inflammatory agent. In supporting the previous results, the study observed mucin 1 as one of the protein involves in the inflammatory pathway in the colon. It is found that there are altered MUC1 expression in patients with IBD, where it is highly expressed. ${ }^{10,30}$ This could be seen from the results of this paper, where the highest mean $\mathrm{H}$-score is in the negative control group or the group given only DSS, with the mean score of 175.39. In comparison the lowest mean $\mathrm{H}$-score is the normal group, which did not receive any DSS.

\section{Treatment of mahkota dewa and effectiveness compared to other}

Mahkota dewa leaf extract is known to have anti-inflammatory effect of the flavonoids inside it, which contain kaempferol, naringin, routine, and myricetin. These compounds can reduce the $\beta$-catenin expression by increasing glycogen synthase kinase 3 beta (GSK-3B or GSK-3 $\beta$ in mice), which will bind to the $\beta$-catenin and inactivate the Wnt signaling pathway. ${ }^{26}$ In addition, kaempferol may also lower the production of proinflammatory cytokines by lowering inducible nitric oxide synthase (iNOS) protein and inhibit endothelial adhesion molecule intercellular adhesion molecule-1 (ICAM-1). ${ }^{23,25}$ Another study by Kusmardi et al., although observing the extract form mahkota dewa pericarp, found the same substance of flavonoids, that also support that this compound have an anti-inflammatory effect, which is by inhibiting NF-kB..$^{25}$ This study also found that myricetin also affecting the NF-kB pathway by degrading IkB and translocation of the p65 subunit in NF-kB. ${ }^{25}$ 
Although this study did not focus on the iNOS protein or directly the expression of NF-kB, Mucin 1 (MUC1) is known to increase in colon epithelial cell if there is a chronic inflammation and cause a negative feedback to $\mathrm{T}$ helper 17 (Th17) to prevent worsening of chronic inflammation. ${ }^{31}$ However, if it last for a long time, then hypoglycosylated MUC1 could be overexpressed and develop into IBD and even adenocarcinoma. ${ }^{32}$ The aberrant glycosylation of MUC1 could also increase the expression of NF-kB families such as Ikk and IkB-a, while also associate with phospho-65 (p65) which will together be translocated to the nucleus and induce more proinflammatory cytokines. ${ }^{30}$ Thus, if there is a reduction of MUC1 expression in the epithelial cell of the colon, it shows that the inflammation was managed properly as it is not over expressed.

The expression of MUC1 protein in the epithelial cell was observed from the immunohistochemistry score or $\mathrm{H}$-score taken from a photo of colon slide, specifically its crypt of lieberkuhn. The mean $\mathrm{H}$-score of each group treatments were in accordance with the theory from previous studies, in which the group given only DSS or known as the negative group have a higher score compared to other treatment groups. In addition, the normal group, which did not receive DSS, shows the lowest $\mathrm{H}$-score compared to other groups, which was 148.02 $(\mathrm{SD}=5.28)$. The differences between the groups if seen from Anova test shows a statistical evidence that the population of mice are significantly different $(\mathrm{p}<.001)$, these results then further seen with post hoc test to see the specific group pairings that are significant. These groups are negative group paired with normal group $(\mathrm{p}<.001)$, aspirin group $(\mathrm{p}=.010)$, and high dose of mahkota dewa group $(\mathrm{p}<.001)$, then there is also two significant pairing between low dose of mahkota dewa group with the normal group $(\mathrm{p}=.007)$ and high dose mahkota dewa group $(\mathrm{p}=.028)$.

The significant result between the negative group with the other three groups shows that both aspirin and the high dose mahkota dewa treatment are effective to treat the inflammation, as the mean $\mathrm{H}$-score was more closer with the normal group. It should be taken note that the mean $\mathrm{H}$-score difference of the high dose mahkota dewa are almost the same as normal group $\left(\mathrm{M}_{\text {dif negative-high dose } \mathrm{MD}}=25.49, \mathrm{SD}_{\text {negative-high dose } \mathrm{MD}}\right.$ $\left.=4.67, \mathrm{p}<.001 ; \mathrm{M}_{\text {dif negative-normal }}=27.37, \mathrm{SD}_{\text {negative-normal }}=4.47, \mathrm{p}<.001\right)$. In comparison, although aspirin are widely used to reduce inflammation in the colon, it does not show expected results of $\mathrm{H}$-score reduction like the high dose mahkota dewa group. This results may correlate to the dosage of aspirin that may not be sufficient enough to inhibit COX-2 enzyme, which is also the conclusion by a previous study. ${ }^{26}$ However, by increasing the dosage of Aspirin would actually inhibit not only COX-2 but also COX-1 which has a function to protect gastrointestinal tract, controlling kidney-renal blood flow, and platelet aggregation, which then cause more complication and reduce the inflammation. ${ }^{33}$ Meanwhile, theoretically the effect of mahkota dewa is to inhibit NF-kB pathway, which is correlated with COX-2 pathway. ${ }^{34}$

Another significant result that should be taken note of is between the low dose and high dose of mahkota dewa group, with difference of mean $\mathrm{H}$-score of 14.37 ( $\mathrm{SD}=4.47, \mathrm{p}=.028$ ). It shows that the dosage for mahkota dewa treatment is important to be established, especially to estimate an appropriate dosage to treat colon inflammation effectively with minimal risk as possible. Especially since a study by Suprapti et al in 2014, found that the administration of high doses of mahkota dewa has killed some mice in the group. ${ }^{26}$ Thus, there could be a risk that should be observed further to see possible side effects in high dose of Mahkota Dewa, even if the result show a positive reduction of MUC1 protein. There should be a continuation of the research to see the effective dosage of mahkota dewa that could be given with lower risk of complications.

\section{CONCLUSION}

From the study, mahkota dewa (Phaleria macrocarpa) leaf extract is concluded to be able to stop the inflammation process and reduce epithelial damage in mice colon as seen from the significant reduction of MUC1 expression in high dosage mahkota dewa group from the negative control group. As for its comparison with aspirin, it shows that the high dosage mahkota dewa is more effective for the reduction of MUC1 expression compared to aspirin, however, it might be caused from the dosage of aspirin used for the group.

\section{COMPETING OF INTEREST}

None to declare.

\section{ACKNOWLEDGEMENTS}

Thank you to Directorate of Research \& Development, Ministry of Research, Technology, and Higher Education Republic of Indonesia / National Agency for Research for the funds provided (PTUPT contract number NKB- 263/UN2.RST/HKP.05.00/2021.

\section{REFERENCES}

1. Ananthakrishnan AN. Epidemiology and risk factors for IBD. Nat Rev Gastroenterol Hepatol [Internet]. 2015;12(4):205-17. Available from: http://dx.doi.org/10.1038/nrgastro.2015.34

2. Kaplan GG. The global burden of IBD: From 2015 to 2025. Nat Rev Gastroenterol Hepatol [Internet]. 2015;12(12):720-7. Available from: http://dx.doi.org/10.1038/nrgastro.2015.150

3. Ng SC, Tang W, Ching JY, Wong M, Chow CM, Hui AJ, et al Incidence and Phenotype of Inflammatory Bowel Disease Based on Results From the Asia-Pacific Crohn's and Colitis Epidemiology Study. Gastroenterology [Internet]. 2013 Jul;145(1):158-165.e2. Available from: http://dx.doi.org/10.1053/j.gastro.2013.04.007

4. Ng WK, Wong SH, Ng SC. Changing epidemiological trends of inflammatory bowel disease in Asia. Intest Res. 2016;14(2):111-9.

5. Simadibrata M, Adiwinata R. Current Issues of Gastroenterology in Indonesia. Acta Med Indones. 2017;49(3):270-8.

6. Strayer DS, Rubin E. Rubin's Pathology Clinicopathologic Foundations of Medicine. 7th ed. Wolters Kluwer. Philadelphia: Wolters Kluwer; 2014. 1464 p.

7. World Health Organization. Indonesia Source GLOBOCAN 2018. Int Agency Res Cancer [Internet]. 2019;256:1-2. Available from: http:// gco.iarc.fr/

8. Abdullah M, Sudoyo AW, Utomo AR, Fauzi A, Rani AA. Molecular profile of colorectal cancer in Indonesia: is there another pathway? Gastroenterol Hepatol from bed to bench [Internet]. 2012;5(2):718. Available from: https://www.ncbi.nlm.nih.gov/pmc/articles/ PMC4017456/

9. Abdullah M, Rani AA, Sudoyo AW, Makmun D, Handjari DR Hernowo BS. Expression of NF-kB and COX2 in colorectal cancer among native Indonesians: the role of inflammation in colorectal carcinogenesis. Acta Med Indones. 2013;45(3):187-92.

10. Dhar P, McAuley J. The role of the cell surface mucin MUC1 as a barrier to infection and regulator of inflammation. Front Cell Infect Microbiol. 2019;9(APR):1-8

11. Beatty PL. MUC1 in the Relationship between Inflammation and Cancer in IBD. University of Pittsburgh; 2006.

12. Sheng $Y H$, Triyana S, Wang R, Das I, Gerloff $K$, Florin TH, et al MUC1 and MUC13 differentially regulate epithelial inflammation in response to inflammatory and infectious stimuli. Mucosal Immunol [Internet]. 2013;6(3):557-68. Available from: http://dx.doi. org/10.1038/mi.2012.98

13. Sabino J, Verstockt B, Vermeire S, Ferrante M. New biologics and small molecules in inflammatory bowel disease: an update. Therap Adv Gastroenterol. 2019;12:1-14. 
14. Coyle C, Cafferty FH, Langley RE. Aspirin and Colorectal Cancer Prevention and Treatment: Is It for Everyone? Curr Colorectal Cancer Rep. 2016;12(1):27-34

15. Kaulmann A, Bohn T. Bioactivity of Polyphenols: Preventive and Adjuvant Strategies toward Reducing Inflammatory Bowel Diseases - Promises, Perspectives, and Pitfalls. Oxid Med Cell Longev. 2016;2016(c).

16. Al-Swayeh OA, Clifford RH, Del Soldato P, Moore PK. A comparison of the anti-inflammatory and anti-nociceptive activity of nitroaspirin and aspirin. Br J Pharmacol. 2000;129(2):343-50.

17. Lin SC, Cheifetz AS. The use of complementary and alternative medicine in patients with inflammatory bowel disease. Gastroenterol Hepatol. 2018;14(7):415-25.

18. Easmin MS, Sarker MZI, Ferdosh S, Shamsudin SH, Yunus K Bin, Uddin MS, et al. Bioactive compounds and advanced processing technology: Phaleria macrocarpa (sheff.) Boerl, a review. J Chem Technol Biotechnol. 2015;90(6):981-91.

19. OR A, JA A, OA O. Review on Phaleria macrocarpa Pharmacological and Phytochemical Properties. Drug Des Open Access. 2016;05(03).

20. Estuningtyas A, Widiasari S, Louisa M, Kusmardi K. The Effect of Mahkota Dewa (Phaleria Macrocarpa L.) Leaf Extract Encapsulated in Chitosan Nanoparticles on iNOS and COX-2 Expression in Dextran Sodium Sulphate-Induced Colitis Mice Model. 2019;12(1):220-7.

21. Kusmardi K, Tumpu NA, Estuningtyas A. Phaleria macrocarpa leaf extract-chitosan nanoparticles supress angiogenesis induced by dextran sodium sulfate in mice colon. Int $\mathrm{J}$ Appl Pharm. 2019;11(Special Issue 6):122-4

22. Eichele DD, Kharbanda KK. Dextran sodium sulfate colitis murine model: An indispensable tool for advancing our understanding of inflammatory bowel diseases pathogenesis. World J Gastroenterol [Internet]. 2017 Sep 7;23(33):6016-29. Available from: http://www. wjgnet.com/1007-9327/full/v23/i33/6016.htm

23. Estuningtyas A, Widiasari S, Kusmardi K. Acute Toxicity of Chitosan Nanoparticles Containing Mahkota Dewa (Phaleria Macrocarpa) Leaf Extract and Anti-Inflammatory Effects in a Dextran Sodium Sulfate-Induced Mouse Model Of Ulcerative Colitis. Int J Appl Pharm [Internet]. 2018 Dec 20;10(1):6. Available from: https:// innovareacademics.in/journals/index.php/ijap/article/view/31407
24. Dharmani $P$, Leung $P$, Chadee K. Tumor necrosis factor- $\alpha$ and Muc2 mucin play major roles in disease onset and progression in dextran sodium sulphate-induced colitis. PLoS One. 2011;6(9)

25. Kusmardi K, Estuningtyas A, Shavera D, Tedjo A, Priosoeryanto BP. The effect of mahkota dewa (Phaleria macrocarpa) (scheff.) fruit pericarp extract on inos in mice colon intermittently-induced by dextran sodium sulfate. Asian J Pharm Clin Res. 2017;10(12):309-12.

26. Suprapti T, Louisa M, Tedjo A, Handjari DR. Antiinflammatory Effect of Mahkota Dewa ( Phaleria macrocarpa ( Scheff .) Boerl .) Leaves Extract on Colon Carcinogenesis Induced by Azoxymethane and Dextran Sodium Sulphate: Focus on the iNOS , $\beta$-catenin and COX-2 Expression. 2014;02(04):511-27

27. Seyed Jafari SM, Hunger RE. IHC optical density score: A new practical method for quantitative immunohistochemistry image analysis. Appl Immunohistochem Mol Morphol. 2017;25(1):e12-3.

28. Kumar MH, Sanjai K, Kumarswamy J, Keshavaiah R, Papaiah L, Divya S. Expression of MUC1 mucin in potentially malignant disorders, oral squamous cell carcinoma and normal oral mucosa: An immunohistochemical study. J Oral Maxillofac Pathol. 2016:20(2):214-8.

29. Chassaing B, Aitken JD, Malleshappa M, Vijay-Kumar M. Dextran Sulfate Sodium (DSS)-Induced Colitis in Mice. Curr Protoc Immuno [Internet]. 2014 Feb 4;104(1):1-7. Available from: https://www.ncbi. nlm.nih.gov/pmc/articles/PMC3624763/pdf/nihms412728.pdf

30. Cascio S, Finn OJ. Intra-and extra-cellular events related to altered glycosylation of MUC1 promote chronic inflammation, tumor progression, invasion, and metastasis. Biomolecules. 2016;6(4):1-16.

31. Nishida A, Lau C, Zhang M, Andoh A, Shi H, Mizoguchi E, et al The Membrane-Bound Mucin Muc1 Regulates T Helper 17-Cell Responses and Colitis in Mice. Gastroenterology. 2012;142(4):865-74.

32. Cascio S, Faylo JL, Sciurba JC, Xue J, Ranganathan S, Lohmueller $\mathrm{JJ}$, et al. Abnormally glycosylated MUC1 establishes a positive feedback circuit of inflammatory cytokines, mediated by NFKB p65 and EzH2, in colitis-associated cancer. Oncotarget. 2017:8(62):105284-98

33. Desai SJ, Prickril B, Rasooly A. Mechanisms of Phytonutrient Modulation of Cyclooxygenase-2 (COX-2) and Inflammation Related to Cancer. Nutr Cancer. 2018;70(3):350-75.

34. Altaf R, Asmawi MZ Bin, Dewa A, Sadikun A, Umar MI. Phytochemistry and medicinal properties of Phaleria macrocarpa (Scheff.) Boerl. extracts. Pharmacogn Rev. 2013;7(13):73-80.

\section{GRAPHICAL ABSTRACT}

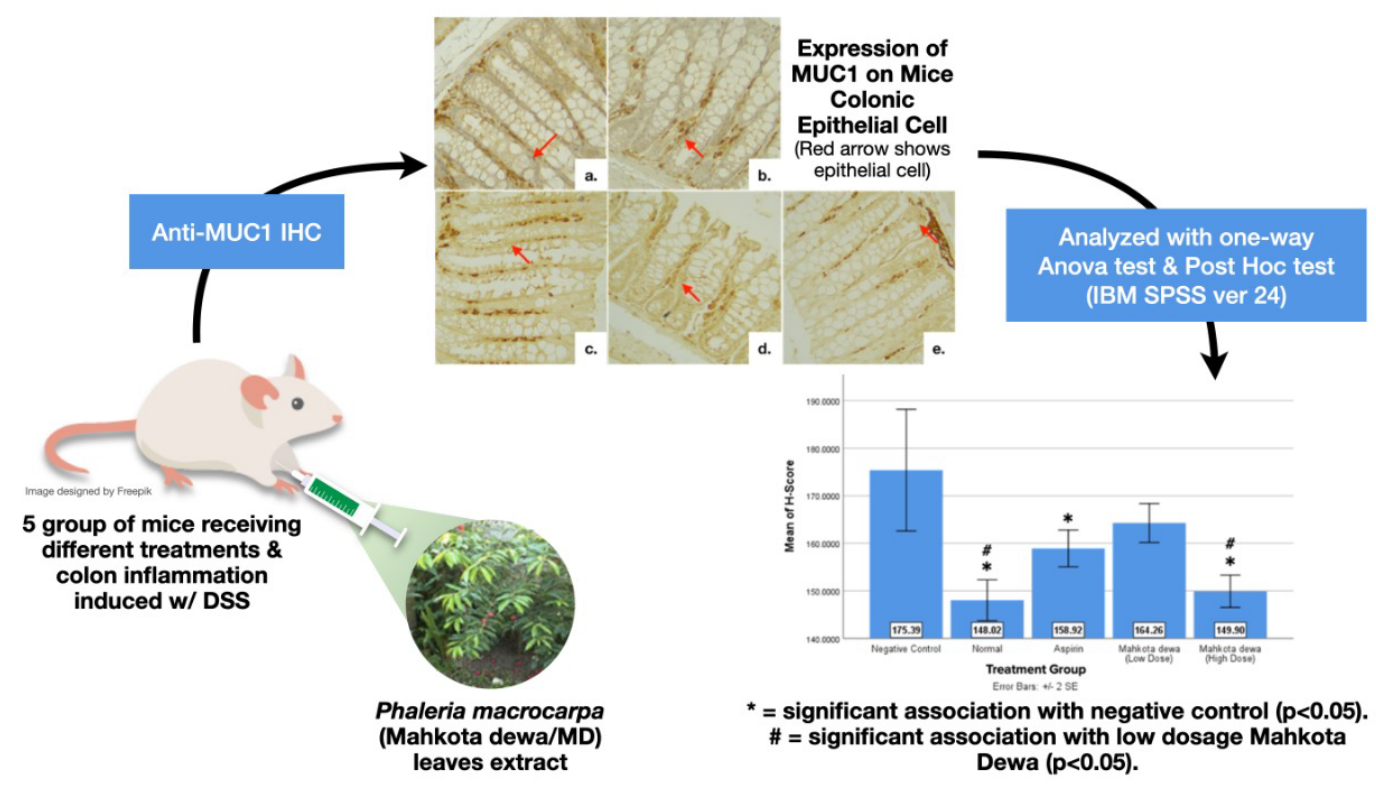




\section{ABOUT AUTHORS}
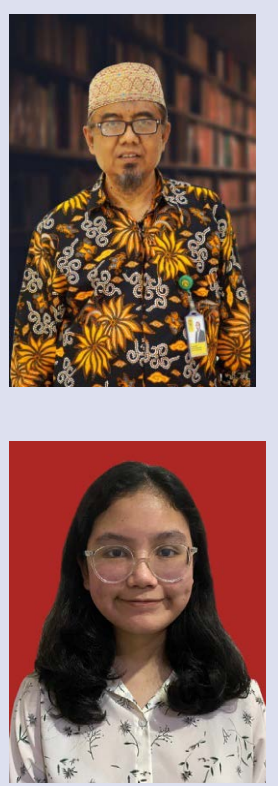

\section{Natasha Yemima Situmorang:}

Faculty of Medicine Universitas Indonesia and Researcher at Pathology Anatomy Department, Faculty of Medicine, Universitas Indonesia. Research interest in Pathology, Herbal Medicine, Gastroenterology, and Congenital Disorders.
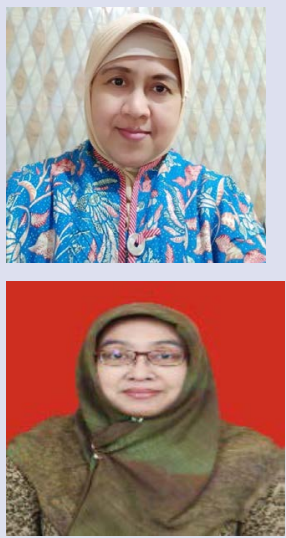

Endah Zuraidah (SSi, M.Epid.) : Lecture and Researcher at Anatomical Pathology Department, Faculty of Medicine, Universitas Indonesia. Reseach interest in Epidemiology of Cancer, Bioinformatics, Animal Models in Herbal Medicine for Cancer Research.

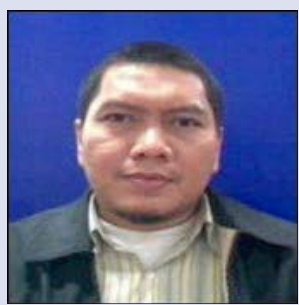

Ari Estuningtyas (M.Sc., Ph.D): Lecturer and Researcher at Pharmacology \& Therapeutics, Faculty of Medicine, Universitas Indonesia. Research interest in Pharmacology, Drug Discovery \& Drug Development, Animal Models in Drug Development, Herbal Medicine, Biomedical Sciences.

Aryo Tedjo (S.Sc., M.Sc): Lecturer and Researcher at Medical Chemistry and Drug Development

Research Center Indonesian Medical Education and Research Institute, Faculty of Medicine, Universitas Indonesia. Research interest in Analytical Chemistry and Herbal Medicine.

Cite this article: Kusmardi K, Situmorang NY, Zuraidah E, Estuningtyas A, Tedjo A. The Effect of Mahkota Dewa (Phaleria macrocarpa) Leaf Extract on the Mucin 1 Expression in Mice Colonic Epithelial Cells Induced by Dextran Sodium Sulfate (DSS). Pharmacogn J. $2021 ; 13(6): 1509-1515$. 